\title{
Retinol-induced changes in the phosphorylation levels of histones and high mobility group proteins from Sertoli cells
}

\section{J.C.F. Moreira, F. Dal-Pizzol, A.B. Rocha, F. Klamt, N.C. Ribeiro, C.J.S. Ferreira and E.A. Bernard}

\author{
Departamento de Bioquímica, Instituto de Ciências Básicas da Saúde, \\ Universidade Federal do Rio Grande do Sul, Porto Alegre, RS, Brasil
}

\section{Correspondence \\ J.C.F. Moreira \\ Departamento de Bioquímica ICBS, UFRGS \\ Rua Ramiro Barcelos, 2600, Anexo 90035-003 Porto Alegre, RS Brasil \\ Fax: + 55-51-316-5535 \\ E-mail: jcfm@ vortex.ufrgs.br}

Research supported by FAPERGS, PRO PESQ -UFRGS, FINEP and CAPES.

Received February 4, 1999 Accepted January 14, 2000

\begin{abstract}
Chromatin proteins play a role in the organization and functions of DNA. Covalent modifications of nuclear proteins modulate their interactions with DNA sequences and are probably one of the multiple factors involved in the process of switch on/off transcriptionally active regions of DNA. Histones and high mobility group proteins (HMG) are subject to many covalent modifications that may modulate their capacity to bind to DNA. We investigated the changes induced in the phosphorylation pattern of cultured Wistar rat Sertoli cell histones and high mobility group protein subfamilies exposed to $7 \mu \mathrm{M}$ retinol for up to $48 \mathrm{~h}$. In each experiment, $6 \mathrm{~h}$ before the end of the retinol treatment each culture flask received $370 \mathrm{KBq} / \mathrm{ml}\left[{ }^{32} \mathrm{P}\right]$-phosphate. The histone and HMGs were isolated as previously described [Moreira et al. Medical Science Research (1994) 22:783-784]. The total protein obtained by either method was quantified and electrophoresed as described by Spiker [Analytical Biochemistry (1980) 108: 263-265]. The gels were stained with Coomassie brilliant blue R-250 and the stained bands were cut and dissolved in $0.5 \mathrm{ml} 30 \% \mathrm{H}_{2} \mathrm{O}_{2}$ at $60^{\circ} \mathrm{C}$ for $12 \mathrm{~h}$. The vials were chilled and $5.0 \mathrm{ml}$ scintillation liquid was added. The radioactivity in each vial was determined with a liquid scintillation counter. Retinol treatment significantly changed the pattern of each subfamily of histone and high mobility group proteins.
\end{abstract}

\section{Introduction}

Although knowledge about the structure of chromatin is still very limited, rapidly evolving theories suggest that chemical modifications of histones and non-histone chromatin-associated proteins are important in determining changes in chromatin configuration(1). Chemical modifications (e.g., phosphorylation and acetylation) of DNA-associ- ated proteins, in particular non-histones, have been correlated with the regulation of cell growth and development, hormone induction, and cellular transformation (1). Furthermore, some reports show a relatively higher content of phosphorylated non-histone chromosomal proteins in less compact, as opposed to densely organized, chromatin regions (2-4). Chromatin packing must be both specific and reversible to allow the

\section{Key words}

- Sertoli cells

- Phosphorylation

- Histones

proteins

- Retinol 
access of factors to regulatory DNA sequences and the access of the transcription apparatus to coding regions of the genome (5-7). Protein phosphorylation plays an important role in several cellular activities, including the initiation of mitosis and regulation of transcription (6).

In an attempt to better understand the mechanisms of retinoid action in Sertoli cells, our group has been studying the effects of treatment with retinol on $\mathrm{N}$-glycoprotein biosynthesis (7), [methyl- $\left.{ }^{3} \mathrm{H}\right]$-thymidine incorporation into DNA $(8,9)$ and nuclear protein phosphorylation(10). Treatment with $10 \mu \mathrm{M}$ retinol for $24 \mathrm{~h}$ increased [methyl- ${ }^{3} \mathrm{H}$ ]-thymidine incorporation into the DNA of cultured rat Sertoli cells, an effect that was not directly related to cell proliferation and was partially inhibited by $3 \mathrm{mM}$ hydroxyurea pre-treatment (9). We have also observed that retinol treatment increases chromatin sensitivity to DNAse I, an effect reversed by pre-treatment with 1,10 phenanthroline (11).

In the present communication, we report studies on the effects of retinol treatment on the phosphorylation of Sertoli cell histones and high mobility group protein (HMG) subfamilies.

\section{Material and Methods}

All-trans-retinol, medium 199, DNAse type I and all other chemicals were purchased from Sigma Chemical Company (St. Louis, MO, USA). [32P]-Phosphate (7.4 GBq/ mmol) was purchased from Amersham International (Amersham Place, Little Chalfont, Buckinghamshire, England).

Sertoli cells were obtained from 15-dayold Wistar rats from our breeding stock. Pregnant rats were housed individually in Plexiglas cages. Litters were culled to eight pups each. The animals were maintained on a 12-h light/dark cycle at a constant temperature of $23^{\circ} \mathrm{C}$, with free access to commercial food and water.

The animals were killed by ether asphyxi- ation, the testes were removed and Sertoli cells were isolated and cultured as previously described (10). After $24 \mathrm{~h}$ in culture with medium 199 supplemented with $1 \%$ fetal calf serum (FCS) at $34^{\circ} \mathrm{C}$ under a normal atmosphere, the cells were washed twice with phosphate-buffered saline (PBS) and cultured for another $24 \mathrm{~h}$ in medium 199. The plating density was $3.2 \times 10^{5}$ cells $/ \mathrm{cm}^{2}$. A small percentage (2-3\%) of contaminating peritubular cells was demonstrated histochemically (7).

After a 24-h culture period without FCS, half of the cells received medium 199 supplemented with $7 \mu \mathrm{M}$ retinol for $6,12,24$ or 48 $h$. The other half of the cells received only the retinol solvent (ethanol $0.1 \%$ ) and were used as the control. In each experiment, $6 \mathrm{~h}$ before the end of retinol treatment each culture flask received $370 \mathrm{KBq} / \mathrm{ml}\left[{ }^{32} \mathrm{P}\right]$-phosphate.

The histone and HMGs were extracted as previously described (10). The total protein obtained by either method was quantified (10) and electrophoresed as described by Spiker (12). The gels were stained with Coomassie brilliant blue R-250 and the stained bands were cut and dissolved in $0.5 \mathrm{ml} \mathrm{30 \%}$ $\mathrm{H}_{2} \mathrm{O}_{2}$ at $60^{\circ} \mathrm{C}$ for $12 \mathrm{~h}$. The vials were chilled and $5.0 \mathrm{ml}$ scintillation liquid was added. The radioactivity in each vial was determined with a liquid scintillation counter.

Results are reported as means \pm SEM $(\mathrm{N}$ $=8$ ). Differences in experimental groups were determined by analysis of variance, followed by the Newman-Keuls test or Student $t$-test when appropriate.

\section{Results}

Table 1 shows the effect of $7 \mu \mathrm{M}$ retinol for different periods of time on histone phosphorylation. Retinol treatment of 12 and 24 h significantly increased total histone phosphorylation and significantly decreased it at 6 and $48 \mathrm{~h}$ compared to controls. Table 2 shows an opposite pattern of induced phos- 
phorylation in HMGs from retinol-treated cells at 6-, 24- and 48-h time points. Based on these data we decided to investigate the effect of retinol treatment on individual subfamilies of histones and HMGs.

Figure 1 (A-D) and 2 (A-D), respectively, show the effect of different times of exposure to $7 \mu \mathrm{M}$ retinol on the phosphorylation of histone and HMG subfamilies. For each treatment period, total histone phosphorylation (all subfamilies) for each treated and untreated group was considered to be $100 \%$ (for each time, the sum specific activities of all subfamilies of treated and untreated (control) cells $=100 \%)$. The objective of this procedure was to compare the phosphorylation pattern, while the intrinsic differences are shown in Tables 1 and 2 .

Treatment with $7 \mu \mathrm{M}$ retinol significantly increased the phosphorylation of the $\mathrm{H} 3$ subfamily at 12,24 and $48 \mathrm{~h}$ as compared to $\mathrm{H} 3$ isolated from control cells. The $\mathrm{H} 3$ phosphorylation level declined during the first 6 $\mathrm{h}$ of retinol treatment. Phosphorylated H3 seems to be involved in DNA synthesis activation during the cell cycle $(13,14)$.

$\mathrm{H} 2 \mathrm{a}$ also showed a significant decrease in phosphorylation at $48 \mathrm{~h}$. At 6 and $24 \mathrm{~h}$ of retinol treatment this subfamily showed an increase in phosphorylation. Phosphorylated $\mathrm{H} 2 \mathrm{a}$ seems to be associated with transcriptionally active chromatin (15).

Increased phosphorylation seems to be associated with transcriptionally active genes in the $\mathrm{H} 2 \mathrm{~b}$ subfamily and with nucleosome stability in the $\mathrm{H} 4$ subfamily $(15,16)$. $\mathrm{H} 4$ and $\mathrm{H} 2 \mathrm{~b}$ showed no significant difference in phosphorylation up to $12 \mathrm{~h}$ of retinol treatment. There was an increase in phosphorylation at $24 \mathrm{~h}$ and a significant decrease at $48 \mathrm{~h}$ of retinol treatment compared with the respective histone group from untreated cells.

The linker histone H1 showed a significant rise in phosphorylation level at all times of retinol treatment as compared with $\mathrm{H} 1$ from control cells. An increase in $\mathrm{H} 1$ phosphorylation is frequently associated with re- laxed chromatin (17).

Figure 2 (A-D) shows that there was no significant change in HMG1 phosphorylation with retinol treatment at 6 or $48 \mathrm{~h}$ compared with control. However, phosphorylation increased significantly at $12 \mathrm{~h}$ and declined significantly at $24 \mathrm{~h}$ of retinol treatment, as compared with HMG1 from untreated cells.

HMG2 from retinol-treated Sertoli cells showed a significant increase in phosphorylation compared to control cells at $6 \mathrm{~h}$, but there was a significant decrease at 12 and 24 $\mathrm{h}$ of treatment. HMG1 and HMG2 are frequently associated with DNA synthesis in

Table 1 - Incorporation of $32 \mathrm{p}-3$ into histones isolated from $7 \mu \mathrm{M}$ retinol-treated rat Sertoli cells.

Histones were isolated from treated and untreated cells at each specified time as described in Material and Methods. Protein was determined by the method of Lowry and radioactivity by liquid scintigraphy. Data are reported as counts $\times 10^{3} / \mathrm{mg}$ protein (means $\pm \mathrm{SEM} ; \mathrm{N}=8$ ); $* \mathrm{P}<0.01$ compared to control at the same time point (Student t-test).

\begin{tabular}{ccc}
\hline Treatment period & Control & Treated \\
\hline $6 \mathrm{~h}$ & $350 \pm 2.1$ & $298 \pm 1.6^{*}$ \\
$12 \mathrm{~h}$ & $365 \pm 3.4$ & $419 \pm 2.2^{*}$ \\
$24 \mathrm{~h}$ & $370 \pm 1.9$ & $462 \pm 3.2^{*}$ \\
$48 \mathrm{~h}$ & $525 \pm 3.7$ & $456 \pm 1.4^{*}$
\end{tabular}

Table 2 - 32p-3 incorporation into high mobility group protein (HMG) isolated from $7 \mu \mathrm{M}$ retinoltreated rat Sertoli cells.

HMGs were isolated from treated and untreated cells at each specified time as described in Material and Methods. Protein was determined by the method of Lowry and radioactivity by liquid scintigraphy. Data are reported as counts $\times 10^{3} / \mathrm{mg}$ protein (means $\pm \mathrm{SEM} ; \mathrm{N}=8$ ). $* \mathrm{P}<0.01$ compared to control at the same time point (Student t-test)

\begin{tabular}{ccc}
\hline Treatment period & Control & Treated \\
\hline $6 \mathrm{~h}$ & $125 \pm 1.1$ & $176 \pm 3.5^{*}$ \\
$12 \mathrm{~h}$ & $137 \pm 4.4$ & $143 \pm 2.2^{*}$ \\
$24 \mathrm{~h}$ & $150 \pm 2.9$ & $112 \pm 4 .^{*}$ \\
$48 \mathrm{~h}$ & $275 \pm 3.4$ & $619 \pm 2.6^{*}$
\end{tabular}


proliferative undifferentiated cells (18). At $48 \mathrm{~h}$ there was no significant difference between HMG2 from treated and untreated cells.

Dephosphorylated HMG14 and HMG17 seem to be associated with transcriptionally active chromatin $(16,19)$. HMG14 from retinol-treated Sertoli cells showed significantly higher phosphorylation after 6 or $48 \mathrm{~h}$ and a significantly lower level at $24 \mathrm{~h}$ of treat-

Figure 1 - Incorporation of 32p-3 into histone subfamilies isolated from $7 \mu \mathrm{M}$ retinol-treated rat Sertoli cells. Sertoli cells were treated with retinol $(7 \mu \mathrm{M})$ for 6 , 12,24 and $48 \mathrm{~h}$ and a $10 \mu \mathrm{Ci} / \mathrm{ml}$ of ${ }^{32} \mathrm{p}^{-3}$ pulse was applied $6 \mathrm{~h}$ before the end of each treatment. Treated cells are indicated by striped columns and controls by open columns. Cells were scraped and washed twice with cold PBS. Histones were isolated, quantified and electrophoresed. The gel was scanned by densitometry, each band was cut and dissolved, and radioactivity was counted by liquid scintigraphy. Percent phosphorylation for each subfamily was related to total histone phosphorylation. For each treatment period, total histone phosphorylation for each treated or untreated group was considered to be $100 \%$ (for each time, the sum of the specific activities of all subfamilies of treated or untreated (control) cells $=100 \%$ ). The objective of this procedure was to compare the phosphorylation pattern, while the intrinsic differences are shown in Tables 1 and 2. Data are reported as means $\pm \mathrm{SEM} ; \mathrm{N}=8$. $* \mathrm{P}<0.01$ compared to untreated control cells (Newman-Keuls test). A, 6$h$ retinol treatment. $B, 12-h$ retinol treatment. C, 24-h retinol treatment. D, 48-h retinol treatment.
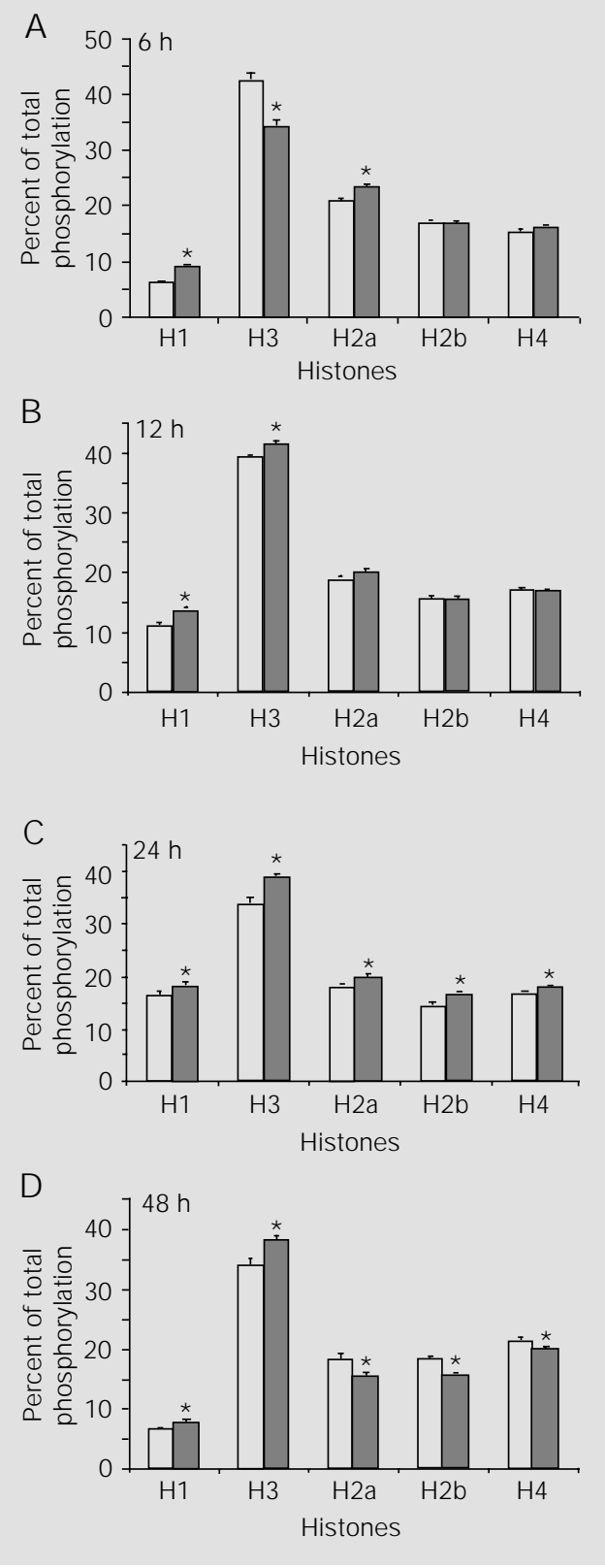

ment as compared with control.

HMG17 from retinol-treated cells showed a decrease in phosphorylation at 6, 12 and 24 $\mathrm{h}$ and an increase at $48 \mathrm{~h}$ as compared with HMG17 from untreated cells.

\section{Discussion}

A number of observations on nucleosome rearrangements and transitions in transcription- and replication-related events suggest that chromatin is a structure capable of considerably dynamic behavior (20-22). Our previous results demonstrated that retinol treatment for $6,12,24$ or $48 \mathrm{~h}$ increased the sensitivity of chromatin to DNAse I (11).

$\mathrm{H} 1$, the linker histone that closes two turns of DNA around the nucleosome, plays an essential role in the formation and stabilization of the $30-\mathrm{nm}$ high-order chromatin fiber (23). Pennings et al. (6) suggest the probable importance of dephosphorylated $\mathrm{H} 1$ as a general repressor of nucleosome mobility. Because of its pivotal role in packaging the genome in the high-order chromatin structure, histone H1 dephosphorylation/ phosphorylation turnover seems to play a role in a general reversible repression mechanism (24-26).

Histone H1 (Figure 1) from retinol-treated cells was more phosphorylated than $\mathrm{H} 1$ from untreated cells at each time studied. Our results are in agreement with those of Takada et al. (27) which indicate an increase in DNA primase activity with an increase in the number of phosphate molecules bound to histone H1. In his review, Lewin (14) suggested that the addition of dephosphorylated $\mathrm{H} 1$ to transcriptional active chromatin causes a rapid decline in transcription. In mobile nucleosomes the restriction of mobility by linker histones (dephosphorylated H1) might be expected to exert a major influence on the accessibility of chromatin to regulatory molecules (28).

$\mathrm{H} 3$ is a very important marker of the cell cycle. Its phosphorylation level determines 
the control of the entry of the cell into phase $\mathrm{S}$ of the cell cycle (6). This subfamily is one of the static components of the nucleosome core. The $\mathrm{H} 2 \mathrm{a}-\mathrm{H} 2 \mathrm{~b}$ dyad from retinol-treated cells showed a change in phosphorylation level from 12 to $24 \mathrm{~h}$ as compared with that from untreated cells. This covalent modification of the dyad (phosphorylation, acetylation or ubiquitination) is frequently associated with transcriptionally active chromatin $(4,17)$. These data, taken together with the increased sensitivity to DNAse I (11) in retinol-treated cells during the same period of time, suggest that chromatin may be more relaxed in retinol-treated cells.

The pattern of HMG subfamily phosphorylation in treated Sertoli cells was different from that in untreated cells, in agreement with our previous data (10).

HMG1 and HMG2 from retinol-treated cells showed decreased levels of phosphorylation at $6 \mathrm{~h}$ compared to control, and this difference persisted until $24 \mathrm{~h}$. At $48 \mathrm{~h}$ there was an inversion in the phosphorylation pattern of this HMG subfamily. HMG1 and HMG2 are associated with linker histones and Kohlstaedt and Cole (3) have reported a strong competition between HMG1 and $\mathrm{H} 1$ for the same interaction site in chromatin $(4,29,30)$.

Although the cellular function of the HMG14/17 proteins is not fully understood, the functions of these proteins very probably depend on proper interaction with nucleosomes in chromatin. HMG14/17 are the only known nuclear proteins which specifically recognize the 146-base pair nucleosomal core particle (31). Chromosomal proteins HMG14/17 may play a role in the generation of structure features which are unique to transcriptionally active genes (19).

HMG14 and 17 specifically bind to nucleosome core particles. Therefore they can be considered an integral part of the chromatin fiber. Multiple specific interactions between the protein and nucleic acid components in chromatin facilitate complex pro- cesses such as replication, DNA repair, recombination, and transcription. These proteins probably may still act as "architectural" elements and facilitate transcription in the context of chromatin, perhaps by negating the repressive effects of histones and inducing structural changes that ease the binding of other factors to their targets. Their modular structure may reflect a requirement for interaction with both the DNA and histone in nucleosomes and may facilitate mul-
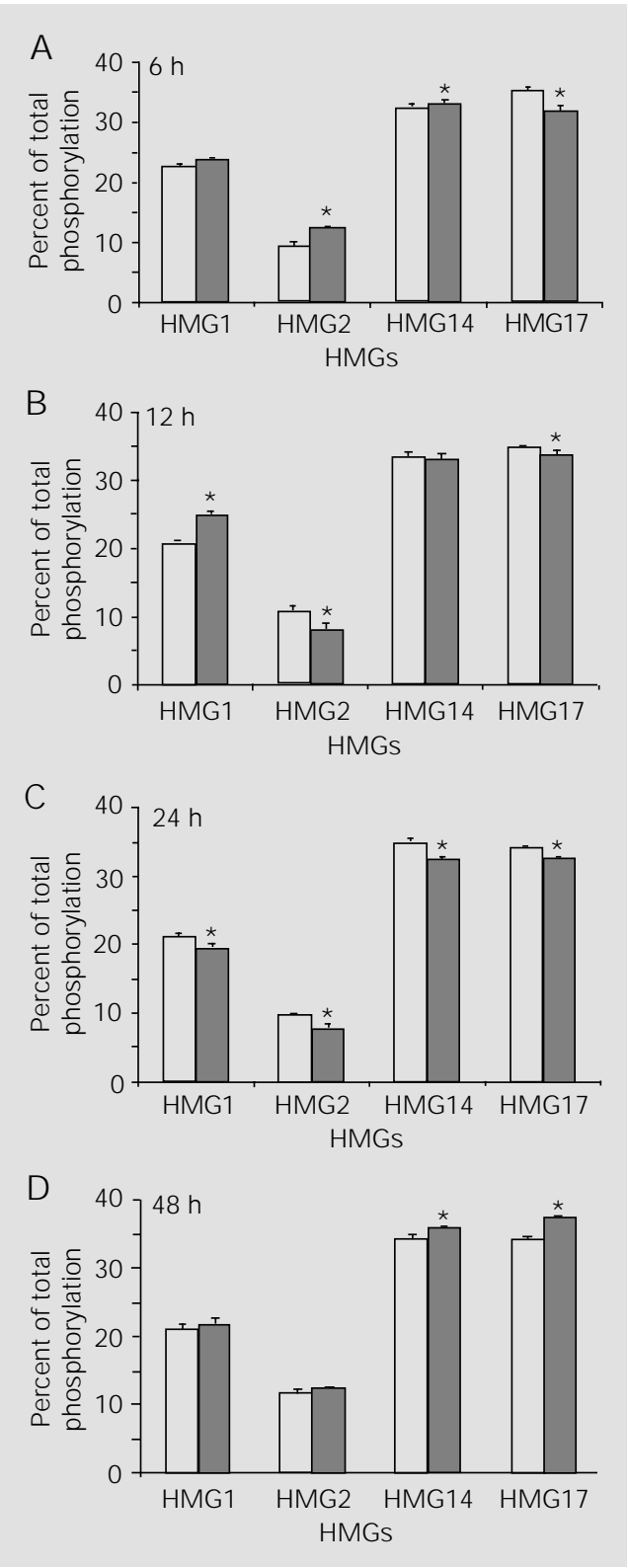

Figure 2 - $32 \mathrm{p}-3$ incorporation into high mobility group protein (HMG) subfamilies isolated from $7 \mu \mathrm{M}$ retinol-treated rat Sertoli cells. Sertoli cells were treated with retinol $(7 \mu \mathrm{M})$ for $6,12,24$ and $48 h$; $6 h$ before the end of each treatment a pulse with 10 $\mu \mathrm{Ci} / \mathrm{ml}$ of ${ }^{32} \mathrm{p}^{-3}$ was applied. Cells were scraped and washed twice with cold PBS. HMGs were isolated, quantified and electrophoresed. The gel was scanned by densitometry, each band was cut and dissolved, and radioactivity was counted by liquid scintigraphy. The percentage of each subfamily phosphorylation is reported in relation to total HMG phosphorylation. For each treatment period, total HMG phosphorylation for each treated or untreated group was considered to be $100 \%$ (for each time, the sum of the specific activities of all subfamilies of treated and untreated (control) cells $=100 \%$ ). The objective of this calculation was to compare the phosphorylation pattern, while the intrinsic differences are shown in Tables 1 and 2 . Data are reported as means \pm $\mathrm{SEM} ; \mathrm{N}=8$. *P $<0.01$ compared to untreated control cells (Newman-Keuls test). A, 6-h retinol treatment. B, 12-h retinol treatment. C, 24-h retinol treatment. D, 48-h retinol treatment. 
tiple cooperative interactions which increase the overall flexibility of multiple component structures such as active chromatin (20).

Tremethick et al. $(15,16)$ proposed that $\mathrm{H} 2 \mathrm{a}$ and $\mathrm{H} 2 \mathrm{~b}$ were replaced in active chromatin by HMG14 and HMG17 and we observed an opposite pattern of phosphorylation between these groups of HMGs and histones (Figures 1 and 2 B,C). Taking into account our previously published results that chromatin from treated cells is more sensitive to DNAse I digestion (11), and the results presented in this paper that chromatin from treated cells also has a higher percentage of phosphorylated histone $\mathrm{H} 2 \mathrm{a}-\mathrm{H} 2 \mathrm{~b}$ and a lower percentage of phosphorylated HMG14 and HMG17 (30), we believe our data are in agreement with the proposals of Tremethick et al. $(15,16)$.

Hansen and Wolffe (32) showed that removal of histone $\mathrm{H} 2 \mathrm{a}-\mathrm{H} 2 \mathrm{~b}$ from nucleosomal assays has a major influence on chromatin compactation and in the repression of RNA polymerase III transcription initiation and elongation. Thus, they propose that one consequence of depletion of $\mathrm{H} 2 \mathrm{a}-\mathrm{H} 2 \mathrm{~b}$ from active chromatin is to stabilize a more extended chromatin structure that will facilitate the entry of RNA polymerase (21). This work suggests that the increased relaxation of chromatin we observed at 24-h retinol treatment was probably due to chromatin activation.

Weisbrod and Weintraub (33) described experiments that define a group of proteins which are easily eluted from chromatin and are responsible in part for increasing the sensitivity of chromatin DNAse I. These proteins correspond to HMG14/17 (30).

The introduction of negatively charged phosphate groups on chromatin-associated proteins is likely to loosen the chromatin structure, and this looseness in chromatin structure could be highly transient. Thus, histone and HMG phosphorylation/dephosphorylation turnover may allow temporary access to DNA during replication, repair, recombination and transcription (23,34-36). Accumulated evidence strongly indicates that one cannot explain gene regulation merely by the interaction between DNA and nuclear proteins. Removal of histone-controlled repression is the necessary step in the turning off of a eukaryotic gene (23). If this conclusion is correct, it becomes important to explain how the ties between histone core and the TATA box are relaxed $(14,17)$.

One may speculate that an increase in the level of histone phosphorylation is necessary but not sufficient to promote all the biological events in chromatin regions engaged in chromatin activation.

The process of HMG and histone phosphorylation/dephosphorylation is dynamic and amino acid residues are continuously phosphorylated/dephosphorylated enzymatically. Chadee et al. (2) observed increased phosphorylation of histone in mouse fibroblasts transformed with an active mitogenactivated protein kinase K. Since retinol alters the pattern of histone and HMG phosphorylation (9), one may ask whether histone and HMG kinases or phosphatases are more active in retinol-treated cells or whether their substrates are more available to enzymes themselves $(32,37)$.

\section{References}

1. Davie J R (1996). Histone modifications, chromatin structure, and the nuclear matrix. J ournal of Cellular Biochemistry, 62: 149-157.

2. Chadee DN, Taylor WR, Hurta RA, Allis CD, Wright JA \& Davie J R (1995). Increased phosphorylation of histone $\mathrm{H} 1$ in mouse fibroblasts transformed with oncogenes or constitutively active mitogenactivated protein kinase. J ournal of Biological Chemistry, 270: 20098-20105.

3. Kohlstaedt LA \& Cole RD (1994). Specific interaction between $\mathrm{H} 1$ histone and high mobility group protein HMG1. Biochemis- try, 33: 570-575.

4. Lee DY, Hayes J J , Pruss D \& Wolffe AP (1993). A positive role for histone acetylation in transcription factor access to nucleosomal DNA. Cell, 72: 73-84.

5. Usachenko SI, Gavin IM \& Bavykin SG (1996). Alterations in nucleosome core 
structure in linker histone-depleted chromatin. J ournal of Biological Chemistry, 271: 3831-3836.

6. Pennings $\mathrm{S}$, Meersseman $\mathrm{G} \&$ Bradbury EM (1994). Linker histones $\mathrm{HI}$ and $\mathrm{H} 5$ prevent the mobility of positioned nucleosomes. Proceedings of the National Academy of Sciences, USA, 91: 10275-10279.

7. Guma FCR \& Bernard EA (1994). Effects of retinol on glycoprotein synthesis by Sertoli cells in culture: dolichyl phosphomannose synthase activation. International J ournal of Andrology, 17: 50-55.

8. Guma FCR, Martini LH \& Bernard EA (1993). Retinol effects in Sertoli cells: [methyl- ${ }^{3} \mathrm{H}$ ] thymidine incorporation in DNA. Medical Science Research, 21: 910.

9. Moreira J CF, Dal-Pizzol F, Guma FCR \& Bernard EA (1996). Effects of pre-treatment with hydroxyurea on the increase in [methyl-3 ${ }^{3}$ ] thymidine incorporation induced by retinol treatment in Sertoli cells. Medical Science Research, 24: 383-384.

10. Moreira J CF, J unqueira LAV, Von Endt $D$ $\&$ Bernard EA (1994). The effect of retinol pre-treatment on the phosphorylation of histones and HMGs from culture Sertoli cells of rats. Medical Science Research, 22: 783-784.

11. Moreira J CF, Dal-Pizzol F, Von Endt D \& Bernard EA (1997). Effect of retinol on chromatin structure in Sertoli cells: 1,10 phenanthroline inhibits the increased DNAse I sensitivity induced by retinol. Medical Science Research, 25: 635-638.

12. Spiker S (1980). A modification of the acetic acid-urea system for use in microlab polyacrylamide gel electrophoresis. Analytical Biochemistry, 108: 263-265.

13. Mathew CG, Goodwin GH \& J ohns EW (1979). Studies on the association of high mobility group non-histone chromatin proteins with isolated nucleosomes. Nucleic Acids Research, 6: 167-179.

14. Lewin B (1994). Chromatin and gene expression: constant questions, but changing answers. Cell, 79: 397-406.

15. Tremethick DJ (1994). High mobility group proteins 14 and 17 can space nucleosomal particles deficient in histones $\mathrm{H} 2 \mathrm{a}$ and $\mathrm{H} 2 \mathrm{~b}$ creating a template that is transcriptionally active. J ournal of Biological Chemistry, 269: 28436-28442.
16. Tremethick DJ \& Drew HR (1993). High mobility group proteins 14 and 17 space nucleosomes in vitro. J ournal of Biological Chemistry, 268: 11389-11393.

17. Pruss D, Hayes JJ \& Wolffe AP (1995). Nucleosomal anatomy - where are the histones? Bioassays, 17: 161-170.

18. Seyedin SM, Pehrson JR \& Cole RD (1981). Loss of chromosomal high mobility group proteins HMG1 and HMG2 when mouse neuroblastoma and Friend erythroleukemia cells become committed to differentiation. Proceedings of the National Academy of Sciences, USA, 78: 5988-5992.

19. Treischmann L, Postnikov YV, Rickers $A \&$ Bustin M (1995). Modular structure of chromosomal proteins HMGl4 and HMG17: definitions of a transcriptional enhancement domain distinct from the nucleosomal binding domain. Molecular and Cellular Biology, 15: 6663-6669.

20. Treischmann L, Alfonso PJ, Crippa MP, Wolffe AP \& Bustin M (1995). Incorporation of chromosomal proteins HMG14/ HMG17 into nascent nucleosomes induces an extend chromatin conformation and enhances the utilization of active transcription complexes. EMBO J ournal, 14: 1478-1489.

21. Green GR, Patel J C, Hecht NB \& Poccia DL (1991). A complex pattern of $\mathrm{H} 2 \mathrm{a}$ phosphorylation in the mouse testis. Experimental Cell Research, 195: 8-12.

22. Chen F \& Wagner PD (1994). 14-3-3 proteins bind to histone and affect both histone phosphorylation and dephosphorylation. FEBS Letters, 347: 128-132.

23. Studitsky VM, Clark DJ \& Felsenfeld G (1994). A histone octamer can step around a transcribing polymerase without leaving the template. Cell, 76: 371-382.

24. Sweet MT, Carlson G, Cook RG, Nelson D \& Allis CD (1997). Phosphorylation of linker histone by a protein kinase A-like activity in mitotic nuclei. J ournal of Biological Chemistry, 272: 916-923.

25. Kamakaka RT \& Thomas J O (1990). Chromatin structure of transcriptionally competent and repressed genes. EMBO J ournal, 9: 3997-4006.

26. Ericsson C, Grossbach U, Björkroth B \& Daneholt B (1990). Presence of histone $\mathrm{H} 1$ on an active Balbiani ring gene. Cell,
60: 73-83.

27. Takada S, Nakagawa A, Yamada I \& Yamamura M (1994). Role of nuclear histone-H1 kinase regeneration of rat liver. Biochemistry and Molecular Biology International, 34: 935-941.

28. Zlatanova J \& Van Holde K (1996). The linker histones and chromatin structure: new twists. Progress in Nucleic Acid Research and Molecular Biology, 52: 217259.

29. Varga-Weisz P, Van Holde $K \&$ Zlatanova J (1996). Competition between linker histones and HMGI for binding to four-way junction DNA: implications for transcription. Biochemical and Biophysical Research Communications, 203: 1904-1911.

30. Bustin M, Treischmann L \& Postnikov YV (1995). The HM G14/17 chromosomal protein family: architectural elements that enhance transcription from chromatin. Seminars in Cell Biology, 6: 247-255.

31. Postnikov YV, Treischmann L, Rickers A \& Bustin M (1995). Homodimers of chromosomal proteins $\mathrm{HMGl}$ and $\mathrm{HMG17}$ in nucleosome cores. J ournal of Molecular Biology, 252: 423-432.

32. Hansen J C \& Wolffe AP (1994). A role for histone $\mathrm{H} 2 \mathrm{a} / \mathrm{H} 2 \mathrm{~b}$ in chromatin folding and transcriptional repression. Proceedings of the National Academy of Sciences, USA, 91: 2339-2343.

33. Weisbrod S \& Weintraub H (1979). Isolation of a subclass of nuclear proteins responsible for conferring a DNAse I-sensitive structure on globinchromatin. Proceedings of the National Academy of Sciences, USA, 76: 630-634.

34. Wade PA \& Wolffe AP (1997). Histone acetyltransferases in control. Current $\mathrm{Bi}$ ology, 7: 82-84.

35. Widom J (1997). Getting around the nucleosomes. Science, 278: 1899-1901.

36. Davies N \& Lindsey GG (1994). Histone $\mathrm{H} 2 \mathrm{~b}$ (and $\mathrm{H} 2 \mathrm{a}$ ) ubiquitination allows normal histone octamer and core particles reconstitution. Biochimica et Biophysica Acta, 1218: 187-193.

37. Ura K, Hayes JJ \& Wolffe AP (1995). A positive role for nucleosome mobility in the transcriptional activity of chromatin templates: restriction by linker. EMBO J ournal, 14: 3752-3765. 